\title{
The small molecule ISRIB reverses the effects of elF $2 \alpha$ phosphorylation on translation and stress granule assembly
}

\author{
Carmela Sidrauski $^{1 *}$, Anna M McGeachy², Nicholas T Ingolia ${ }^{2}$, Peter Walter ${ }^{1 *}$ \\ ${ }^{1}$ Department of Biochemistry and Biophysics, Howard Hughes Medical Institute, \\ University of California, San Francis, San Francisco, United States; ${ }^{2}$ Department of \\ Molecular and Cell Biology, University of California, Berkeley, Berkeley, United States
}

Abstract Previously, we identified ISRIB as a potent inhibitor of the integrated stress response (ISR) and showed that ISRIB makes cells resistant to the effects of elF2 $\alpha$ phosphorylation and enhances long-term memory in rodents (Sidrauski et al., 2013). Here, we show by genome-wide in vivo ribosome profiling that translation of a restricted subset of mRNAs is induced upon ISR activation. ISRIB substantially reversed the translational effects elicited by phosphorylation of elF2 $\alpha$ and induced no major changes in translation or mRNA levels in unstressed cells. elF $2 \alpha$ phosphorylation-induced stress granule (SG) formation was blocked by ISRIB. Strikingly, ISRIB addition to stressed cells with pre-formed SGs induced their rapid disassembly, liberating mRNAs into the actively translating pool. Restoration of mRNA translation and modulation of SG dynamics may be an effective treatment of neurodegenerative diseases characterized by elF $2 \alpha$ phosphorylation, SG formation, and cognitive loss.

DOI: 10.7554/eLife.05033.001

\section{Introduction}

*For correspondence: carmelas@me.com (CS); Peter. Walter@ucsf.edu (PW)

Competing interests: The authors declare that no competing interests exist.

Funding: See page 12

Received: 07 October 2014 Accepted: 04 February 2015 Published: 26 February 2015

Reviewing editor: David Ron, University of Cambridge, United Kingdom

(c) Copyright Sidrauski et al. This article is distributed under the terms of the Creative Commons Attribution License, which permits unrestricted use and redistribution provided that the original author and source are credited.
Diverse cellular conditions activate an integrated stress response (ISR) that rapidly reduces overall protein synthesis while sustaining or enhancing translation of specific transcripts whose products support adaptive stress responses. The ISR is mediated by diverse stress-sensing kinases that converge on a common target, serine 51 in eukaryotic translation initiation factor alpha (elF2 $\alpha$ ) eliciting both global and gene-specific translational effects (Harding et al., 2003; Wek et al., 2006). Mammalian genomes encode four elF2 $\alpha$ kinases that drive this response: PKR-like endoplasmic reticulum (ER) kinase (PERK) is activated by the accumulation of unfolded polypeptides in the lumen of the ER, general control non-derepressible 2 (GCN2) kinase by amino acid starvation and UV light, protein kinase RNA-activated (PKR) by viral infection, and heme-regulated elF2 $\alpha$ kinase (HRI) by heme deficiency and redox stress. The elF $2 \alpha$ kinase PERK is also part of the unfolded protein response (UPR). This intracellular stress signaling network is comprised of three ER-localized transmembrane sensors, IRE1, ATF6, and PERK, which initiate unique signaling cascades upon sensing an increase in unfolded proteins in the ER lumen (Walter and Ron, 2011; Pavitt and Ron, 2012).

The common mediator of the ISR, elF2 $\alpha$, is a subunit of an essential translation initiation factor conserved throughout eukaryotes and archaea. The heterotrimeric elF2 complex (composed of subunits $\alpha, \beta$ and $\gamma$ ) brings initiator methionyl tRNA (Met-tRNA $A_{i}$ ) to translation initiation complexes and mediates start codon recognition. It binds GTP along with Met-tRNA $A_{i}$ to form a ternary complex (elF2GTP-Met-tRNA $A_{i}$ ) that assembles, along with the $40 \mathrm{~S}$ ribosomal subunit and several other initiation factors, into the $43 \mathrm{~S}$ pre-initiation complex (PIC). The 43S PIC is recruited to the $5^{\prime}$ methylguanine cap of an mRNA and scans the 5'UTR for an AUG initiation codon (Hinnebusch and Lorsch, 2012). Start site codon recognition triggers GTP hydrolysis and phosphate release, which is followed by release of 
eIF2 from the $40 \mathrm{~S}$ subunit, allowing binding of the $60 \mathrm{~S}$ ribosomal subunit to join. After these events, the elongation phase of protein synthesis ensues. To engage in a new round of initiation, the newly released eIF2 complex has to be re-loaded with GTP, a reaction catalyzed by its dedicated guanine nucleotide exchange factor (GEF), the heteropentameric eukaryotic initiation factor 2B (elF2B). Phosphorylation of elF2 $\alpha$ does not directly affect its function in the PIC, but rather inhibits elF2B, thereby depleting ternary complex and reducing translation initiation (Krishnamoorthy et al., 2001). elF2B complex is limiting in cells, present in lower abundance than elF2; a small amount of phosphoelF2 $\alpha$ therefore acts as a competitive inhibitor with dramatic effects on elF2B activity. When elF2B is inhibited and ternary complex is unavailable, the rate of translation initiation decreases.

Unimpaired elongation in the face of reduced initiation allows translating ribosomes to run off of their mRNAs, generating naked mRNAs that can then bind to RNA-binding proteins (RBPs) and form messenger ribonucleoproteins, which can further assemble into stress granules (SGs). These cytoplasmic, non-membrane bounded organelles contain translationally stalled and silent mRNAs, $40 \mathrm{~S}$ ribosomal subunits and their associated pre-initiation factors and RBPs; these RBPs facilitate the nucleation and reversible aggregation of SGs through reversible, low-affinity protein-protein interactions mediated by their low complexity domains (Buchan and Parker, 2009; Kedersha and Anderson, 2009; Kato et al., 2012).

Paradoxically, under conditions of reduced ternary complex formation and protein synthesis, a group of mRNAs is translationally up-regulated. These mRNAs contain short upstream open reading frames (uORFs) in their $5^{\prime}$ UTRs, which are required for their ISR-responsive translational control (Hinnebusch, 2005; Jackson et al., 2010). These target transcripts include mammalian ATF4 (a cAMP response element binding transcription factor) and CHOP (a pro-apoptotic transcription factor) (Harding et al., 2000; Vattem and Wek, 2004; Palam et al., 2011). ATF4 regulates the transcription of many genes involved in metabolism and nutrient uptake and thus is a major regulator of the transcriptional changes that ensue upon elF2 $\alpha$ phosphorylation and ISR induction (Harding et al., 2003). Although activation of this cellular program can initially mitigate the stress and confer cytoprotection, persistent and severe stress and its associated reduction in protein synthesis and CHOP activation lead to apoptosis (Tabas and Ron, 2011; Lu et alo, 2014).

In animals, the ISR has been implicated in diverse processes ranging from the regulation of insulin production to learning and memory. These effects were studied first using genetics by generating knockout mice lacking individual elF2 $\alpha$ kinases as well as a knock-in of the non-phosphorylatable allele elF2 $\alpha^{551 A}$ (Eif2s $1^{\text {S51A }}$ ). Homozygous loss of elF2 $\alpha$ phosphorylation leads to perinatal death but heterozygous elF $2 \alpha^{+/ 551 A}$ animals, which have reduced levels of elF2 $\alpha$ phosphorylation, grow into healthy adults showing phenotypes that demonstrate the importance of translation initiation in establishment of long-term memories (Scheuner et al., 2001). Behavioral tests demonstrated that PKR ${ }_{-1-}^{-}, \mathrm{GCN}^{-1-}$ and elF2 $\alpha^{+/ 551 \mathrm{~A}}$ animals display enhanced memory consolidation in learning paradigms of light training (Costa-Mattioli et alo, 2005, 2007; Zhu et al., 2011). Pharmacological modulation of elF2 $\alpha$ phosphorylation represented an important advance, allowing easier discrimination between developmental and acute effects of ISR reduction and circumventing the lethal phenotype of homozygous elF2 $\alpha^{\text {S51A/S51A }}$. Recent work identified small molecules that modulate the ISR pathway at distinct steps: (1) kinase inhibitors that target PERK or PKR (Jammi et alo, 2003; Atkins et alo, 2013); (2) an activator of HRI (Chen et alo, 2011); (3) salubrinal, an inhibitor of elF2 $\alpha$ phosphatases (Boyce et alo, 2005); and (4) ISRIB (Sidrauski et al., 2013). By a yet unknown mechanism, ISRIB blunts the effects of elF2 $\alpha$ phosphorylation in cells and thus represents the first bona fide ISR inhibitor acting downstream of all elF2 $\alpha$ kinases.

Here, we show that ISRIB reverses comprehensively and specifically the effects of elF2 $\alpha$ phosphorylation. By profiling the genome-wide translational program downstream of the ISR, we present the application of ribosome profiling to the ISR in mammalian cells, which allowed us to identify and quantify the translational changes that take place upon its induction and ISRIB treatment. Moreover, live cell imaging revealed that ISRIB addition can trigger a remarkably fast dissolution of phospho-elF2 $\alpha$-dependent SGs in stressed cells, restoring translation.

\section{Results}

\section{Ribosome profiling of ER stress in mammalian cells}

We used ribosome profiling to characterize translational changes induced by ER stress. Deep sequencing of ribosome-protected mRNA fragments provides global, quantitative measurements of 
translation and reveals the precise location of ribosomes on each mRNA (Ingolia et al., 2009, 2011). We triggered the UPR in HEK293T cells by treating them with tunicamycin $(\mathrm{Tm})$, a toxin that blocks Nlinked glycosylation of ER-resident proteins. We chose to analyze an early time point (1 hr) in order to focus on translational changes preceding the extensive transcriptional induction that takes place upon activation of the three branches of the UPR (for a time course of UPR induction, see Figure 3-figure supplement 1 in 10.7554/eLife.00498). After $1 \mathrm{hr}$ of Tm or mock treatment, we added cycloheximide $(\mathrm{CHX})$ to arrest translating ribosomes, lysed the cells, and digested the extract with nuclease to degrade mRNAs not protected by ribosomes. In parallel, we isolated total mRNAs to monitor any changes in mRNA levels. Ribosome profiling data revealed a discrete subset of mRNAs that were translationally up- or down-regulated more than twofold after UPR induction (Figure 1A, above or below box) as seen by changes in abundance of ribosome-protected fragments (RPF) ('Ribo-Seq', $y$-axis) without corresponding changes in mRNA levels ('mRNA-Seq', $x$-axis). Data points representing statistically significant changes in expression between Tm-treated and untreated ('UT') samples are highlighted in black.

Consistent with the well-established presence of regulatory uORFs in their $5^{\prime}$-UTRs, this genomewide analysis identified four previously extensively studied mRNAs that displayed significant translational upregulation: ATF4, ATF5, CHOP, and GADD34, (Figure 1A, colored pink). The mRNAs encoding the closely paralogous transcription factors ATF4 and ATF5 are known translational targets of the ISR (Lu et al., 2004; Vattem and Wek, 2004; Zhou et al., 2008). They contain two uORFs (the second one overlapping with the coding sequence [CDS]) that govern their enhanced translational efficiency. The mRNAs encoding the pro-apoptotic transcription factor CHOP and the regulatory subunit of the elF2 $\alpha$ phosphatase GADD34 were also significantly upregulated at the translational level. Although both CHOP and GADD34 are also known transcriptional targets of ATF4, we did not detect significant induction of their mRNAs at this early time point (Figure 1A, lack of displacement along $x$-axis) indicating that at the time point chosen our analysis exclusively reports on translational effects. CHOP and GADD34 mRNAs also contain uORFs that allow for translational regulation upon elF2 $\alpha$ phosphorylation (Lee et alo, 2009; Palam et al., 2011).

We identified a total of 78 mRNAs whose translation changed significantly and substantially (more than twofold) upon ER stress in HEK293T cells (listed in Figure 1-source data 2A). GO term analysis revealed the involvement of these genes in diverse functions and several encode for proteins with entirely unknown functions. Besides the four known ISR translational targets described above, six mRNAs in the list contain previously mapped uORFs as validated by ribosome profiling in the presence of a translation initiation inhibitor to mark initiation sites (Figure 1A, colored green and Figure 1-source data 2B) (Lee et al., 2012). Whereas $5 \%$ of the non-significantly changed genes in the Tm sample contain previously identified AUG-initiated uORFs, $14 \%$ of genes in the list of ISR-translational targets contain uORFs, indicating a significant enrichment ( $p \leq 0.003$, chi-squared test with Yates correction).

A seventh and novel uORF-containing translational target of the ISR encodes SLC35A4, a putative nucleotide-sugar transporter (Song, 2013). It was recently shown that the longest uORF of SLC35A4 is indeed translated because peptides corresponding to the encoded polypeptide were found in a whole proteome mass spectrometry study (Kim et al., 2014). Analysis of RPFs in the UORFs of the SLC35A4 and ATF4 mRNAs revealed significant ribosome density, further confirming that these regulatory uORFs are normally translated (Figure 1-figure supplement 1). Due to the reduced mRNA expression levels of ATF5, CHOP, and GADD34 in the absence of stress or at early time-points of UPR activation, we did not analyze the RPFs or mRNA reads at specific locations along these genes, as the read numbers were low.

Interestingly, there was a slight reduction in translation of mRNAs encoding ribosomal proteins and translation elongation factors (Figure 1-figure supplement 2, panel A). The translation of this functionally related class of $\sim 100$ abundant mRNAs, which have a $5^{\prime}$ terminal oligopyrimidine (5' TOP) motif, is controlled by the activity of the mTOR kinase (Meyuhas, 2000; Tang et al., 2001; Hsieh et al., 2012; Thoreen et al., 2012). The concerted changes that we observed in their translation upon UPR activation suggest that ER stress and elF2 $\alpha$ phosphorylation affects $5^{\prime}$ TOP translation in HEK293T cells.

\section{ISRIB substantially reduced the translational effects elicited by stress and elF2 $\alpha$ phosphorylation}

To study the translational effects of the small molecule ISRIB at a genome-wide level, we analyzed changes in RPFs and mRNA levels after addition of the drug to both ER-stressed and unstressed cells. 


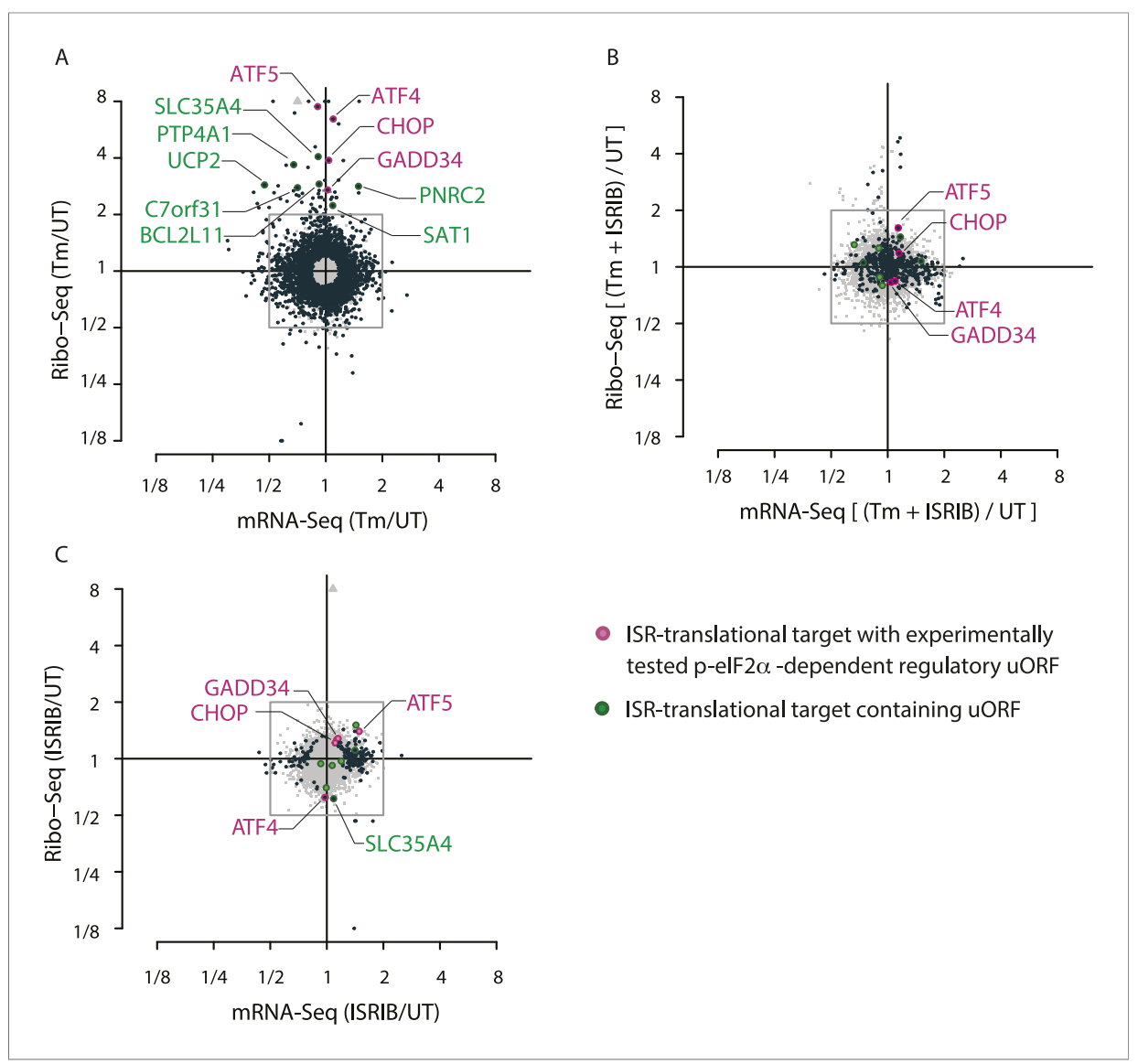

Figure 1. Translational regulation upon ER stress in mammalian cells. (A) Translational and mRNA changes in HEK293T cells upon ER stress. HEK293T cells were treated with or without $1 \mu \mathrm{g} / \mathrm{ml}$ of Tm for $1 \mathrm{hr}$. The $\mathrm{y}$-axis represents fold changes in ribosome-protected fragments (Ribo-Seq) between Tm-treated and control samples. The $x$-axis represents fold changes in mRNA levels (mRNA-Seq) between Tm-treated and control samples. Data points reflecting significant changes (FDR-corrected $p$-value < 0.1) between Tm treated and untreated ('UT') samples are shown in black and non-significant changes are shown in light grey. Note that genes with significant changes (black circles) are numerous in Tm-treated cells and thus the cloud of genes with no significant changes (grey circles) is mostly hidden in the background. Genes with substantially enhanced RFPs and uORFs that are known to be phospho-elF2 $\alpha$-dependently regulated are labeled pink. ISR-translational targets that contain previously identified uORFs are labeled in green. Triangles denote genes that fall beyond the axis range. The genes inside the grey box are those that change less than twofold in RPF or mRNA reads. Figure 1-source data 2A contains a list of all genes that change more than twofold in RPFs during Tm induction (FDR-corrected p-value $<0.1$, corresponding to black circles above and below the box). (B) Translational and mRNA changes in cells co-treated with Tm and ISRIB. HEK293T cells were treated with or without $1 \mu \mathrm{g} / \mathrm{ml}$ of Tm and $200 \mathrm{nM}$ ISRIB for $1 \mathrm{hr}$. The $y$-axis represents fold changes in ribosome-protected fragments (Ribo-Seq) between Tm + ISRIB-treated and control samples. The x-axis represents fold changes in mRNA levels (mRNA-Seq) between Tm + ISRIB-treated and control samples. Genes that significantly change when ISRIB co-administration modulates the effects of Tm treatment are shown in black (FDRcorrected $\mathrm{p}$-value $<0.1$ ). Figure 1 - source data $2 \mathrm{C}$ contains a list of all genes that change more than twofold in RPFs during Tm and ISRIB treatment (FDR-corrected p-value $<0.1$ ). The identity of the ISR-translational targets that contain previously identified uORFs (labeled in green) was not included in this panel as they all collapsed to the center of the plot. (C) Translational and mRNA changes in ISRIB-treated cells. HEK293T cells were treated with or without $200 \mathrm{nM}$ ISRIB for $1 \mathrm{hr}$. The y-axis represents fold changes in ribosome-protected fragments (Ribo-Seq) between ISRIB-treated and control samples. The x-axis represents fold changes in mRNA levels (mRNA-Seq) between ISRIB-treated and control samples. Data points reflecting significant changes (FDR-corrected p-value $<0.1$ ) between ISRIB-treated and untreated ('UT') samples are shown in black and non-significant changes are shown in light grey. Figure 1-source data 2D contains a list of all genes that change more than twofold in RPFs during ISRIB treatment (FDR-corrected p-value $<0.1$, corresponding to black circles outside of the box). ATF4 and SLC35A4 (labeled in this panel) showed reduced translational efficiency upon addition of ISRIB. Two biological replicates were analyzed per condition. Number of reads aligned to the genome and ORFs for all samples are Figure 1. continued on next page 
Figure 1. Continued

found in Figure 1-source data 2E. Correlation plots for the replicates for each condition are found in Figure 1-figure supplement 3. mRNA abundance for all ORFs mapped are found in Figure 1-figure supplement 4. Read counts for all conditions and each individual transcript are found in Figure 1-source data 1. The Ribo-seq and mRNA-seq data have been deposited in NCBI's Gene Expression Omnibus and are accessible through GEO series accession number GSE65778.

DOI: 10.7554/eLife.05033.002

The following source data and figure supplements are available for figure 1:

Source data 1. Read counts for all conditions and each individual transcript.

DOI: 10.7554/eLife.05033.003

Source data 2. Source data for Figure 1.

DOI: 10.7554/eLife.05033.004

Figure supplement 1. Ribosome and mRNA densities in the 5'UTR of ATF4 and SLC35A4. DOI: 10.7554/eLife.05033.005

Figure supplement 2. Translational regulation of mTOR targets upon ER-stress. DOI: 10.7554/eLife.05033.006

Figure supplement 3. Correlation plots for duplicate ribosome profiling experiments. DOI: 10.7554/eLife.05033.007

Figure supplement 4. Mean mRNA abundance of all genes mapped. DOI: 10.7554/eLife.05033.008

As seen in Figure 1B, ISRIB comprehensively blocked the translational changes that take place upon ER-stress. A large number of genes with a significant change in expression upon stress collapsed to the center of the plot with ISRIB and Tm co-treatment (Figure 1B, highlighted in black). Importantly, ISRIB abolished the induction of the known phospho-elF2 $\alpha$-dependent translational targets (Figure 1B, colored pink) and the seven ISR-translational targets with previously identified uORFs (Figure 1B, colored green). The mRNAs that remained translationally induced in the presence of ISRIB are listed in Figure 1-source data 2C. In addition, ISRIB reversed the reduction in translation of mTOR target mRNAs upon ER stress (Figure 1-figure supplement 2, panel B).

Importantly, ISRIB treatment alone did not have general effects on translation in non-stressed cells, as revealed by the lack of substantial changes in RPFs in most cellular mRNAs, nor did it cause any significant changes in mRNA levels (Figure 1C) and mTOR target expression (Figure 1-figure supplement 2, panel C). In the absence of ER stress, ISRIB-treated cells behaved like untreated cells with the exception of a reduction in the basal level of translation of ATF4 and SLC35A4 mRNAs and a few additional mRNAs (Figure 1C and Figure 1-source data 2C). Taken together, these data strongly support the notion that ISRIB does not have global effects on translation, transcription, or mRNA stability in non-stressed cells and underscores its remarkable ability to counteract selectively the translational changes elicited by elF $2 \alpha$ phosphorylation in stressed cells.

\section{ISRIB prevents formation of stress granules exclusively triggered by elF2 $\alpha$ phosphorylation}

Phosphorylation of elF2 $\alpha$ and reduction of ternary complex formation are tightly linked to the formation of stress granules (SGs) (Kedersha et al., 2002). ISRIB renders cells insensitive to the effects of elF2 $\alpha$ phosphorylation, thus leading to the prediction that it prevents SG formation as well. We tested this hypothesis by inducing SG formation using thapsigargin ( $\mathrm{Tg}$ ), a potent ER stressor that inhibits the ER calcium pump and was recently shown by ribosome profiling to yield analogous translational effects to tunicamycin (Reid et al., 2014). Microscopic detection of SGs required a stronger induction of ER stress than commonly achieved with Tm, making $\mathrm{Tg}$ the preferred inducer. We monitored SGs by performing immunofluorescence on elF3a, a translation initiation factor that is recruited into SGs. As expected, we found that ISRIB significantly reduced their assembly upon cotreatment with Tg (Figure 2A,B). In addition, ISRIB prevented SG formation induced by arsenite (Ars), another widely used inducer of elF $2 \alpha$ phosphorylation via activation of HRI. As expected, both treatments induced elF2 $\alpha$ phosphorylation but only Tg induced the ER-resident kinase, PERK, as seen by its shift in mobility that is due to its extensive auto-phosphorylation (Figure 2C). Both the 
PERK mobility shift and elF2 $\alpha$ phosphorylation elicited by Tg treatment were blocked by a PERK inhibitor (GSK707800; Axten et al., 2012) but not by ISRIB. Like ISRIB, and as expected by the block in elF2 $\alpha$ phosphorylation, the GSK PERK inhibitor prevented SG induction upon Tg addition (Figure 2A).

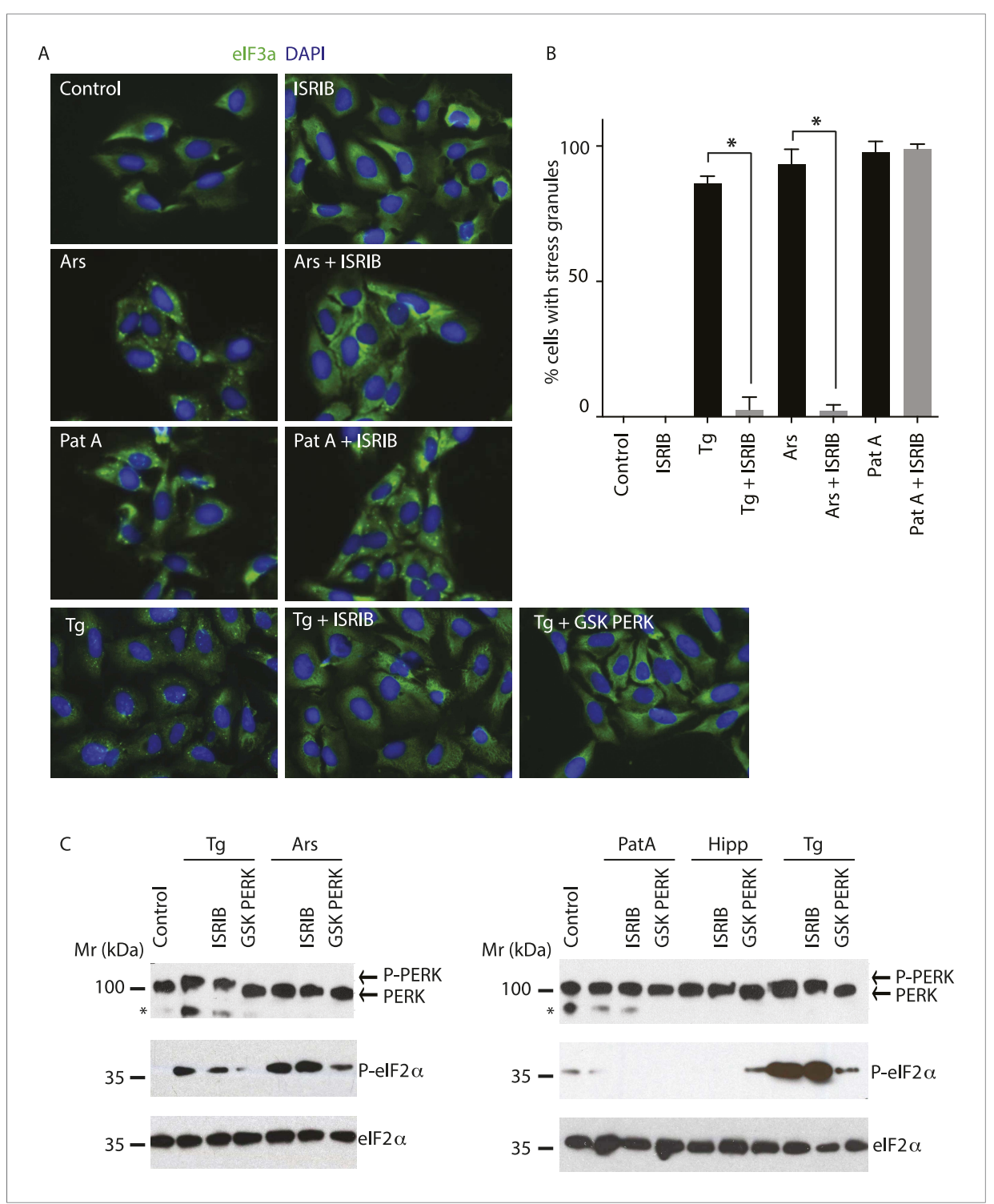

Figure 2. ISRIB blocks stress granule formation induced by elF2 $\alpha$ phosphorylation. (A) Immunofluorescence analysis (elF3a) of U2OS cells treated with $200 \mathrm{nM}$ Tg for $1 \mathrm{hr}, 250 \mu \mathrm{M}$ Ars for $30 \mathrm{~min}$, or $100 \mathrm{nM}$ Pat A for $30 \mathrm{~min}$ in the presence or absence of $200 \mathrm{nM}$ ISRIB or $1 \mu \mathrm{M}$ GSK797800 PERK inhibitor. A secondary Alexa Dye 488 anti-rabbit antibody was used to visualize elF3a and DAPI was used to visualize nuclei. Representative images of at least two biological replicates are shown. (B) Quantitation of the percentage of cells containing stress granules in the different conditions described in $\mathbf{A}$. Images were collected from at least two independent experiments and the number of cells with SGs or no SGs counted. The total number of cells counted for each condition was (sum of all replicates): Control $(N=81)$, ISRIB ( $N=94), \operatorname{Tg}(N=122), \operatorname{Tg}+$ ISRIB $(N=71)$, Ars $(N=85)$, Ars + ISRIB $(N=84)$, Pat $A(N=47)$ and Pat A + ISRIB (N = 64). No cells had SGs in Tg + PERK inh $(N=71)$. p-values are derived from a Student's t-test, ${ }^{*} \mathrm{p}<0.05$. (C) Immunoblot analysis of PERK, phospho elF2 $\alpha$, and total elF2 $\alpha$ in U2OS cells treated as in $\mathbf{A}$. Hippuristanol (Hipp) was used at $300 \mathrm{nM}$ for $30 \mathrm{~min}$. The right blot was overexposed to confirm the absence of induction of elF2 $\alpha$ phosphorylation upon Pat A and Hipp treatment. A representative blot of three independent experiments is shown. The asterisk $\left(^{\star}\right)$ represents a background band or degradation product.

DOI: 10.7554/eLife.05033.009 
SG formation can also be induced in the absence of elF2 $\alpha$ phosphorylation by inhibiting the elF4A helicase, which is part of the cap-binding elF4F complex (Mazroui et al., 2006). Pateamine A (Pat A) binds to and inhibits this enzyme and blocks scanning of the PIC and translation initiation (Dang et al., 2006). In agreement, Pat A-induced SG formation but it did not cause elF2 $\alpha$ phosphorylation (Figure 2A,C). In contrast to phospho-elF2 $\alpha$-induced SGs, Pat-A-induced SGs were not reduced by ISRIB (Figure 2A,B). Thus, ISRIB blocks phospho-elF2 $\alpha$-dependent SG induction selectively.

\section{ISRIB triggers rapid disassembly of stress granules and restores translation}

To visualize SG formation in living cells and to assess the effects of ISRIB on pre-formed SGs, we took advantage of a stable cell line expressing G3BP fused to GFP (Kedersha et al., 2008). In contrast to cell lines that overexpress SG-associated RNA binding proteins like G3BP, in this single clone-derived cell line, low expression of the fusion protein preserves stress-dependent regulation of SG assembly. We confirmed that in this cell line ISRIB significantly reduces SG formation driven by stresses that cause elF2 $\alpha$ phosphorylation (Tg and Ars) but not by phospho-elF2 $\alpha$-independent induction through elF4A inhibition (Pat A and hippuristanol [Hipp]) (Figure 3A,B) (Cencic et al., 2012). To match the strength of the stresses used in these experiments and minimize the toxic effects of these agents, we used the shortest incubation time and the lowest concentration of each stressor that resulted in SG formation in the majority of cells. ISRIB has an $\mathrm{EC}_{50}$ of $5 \mathrm{nM}$ as previously measured using an uORFsATF4-driven luciferase reporter in HEK293T cells (Sidrauski et al., 2013). In close agreement with the high potency measured in the reporter assay, ISRIB significantly reduced SG formation even at concentrations as low as $2 \mathrm{nM}$ in U2OS cells and as expected, an inactive analog, ISRIB ${ }^{\text {inact, }}$, did not reduce their formation (Figure 3-figure supplement 1).

Treatment of cells with $\mathrm{CHX}$ disassembles SGs in the presence of ongoing stress (Kedersha et al., 2000; Mollet et al., 2008). This observation as well as other pharmacological and microscopy data revealed that SGs are highly dynamic structures with mRNAs quickly shuttling in and out. When these mRNAs leave SGs, translation is reinitiated; $\mathrm{CHX}$ then immobilizes elongating ribosomes and prevents mRNA re-entry into SGs. Because polyribosome disassembly is blocked by CHX yet required for SG assembly, CHX treatment dissolves pre-formed SGs. As seen in Figure 3C, a 10-min treatment with $\mathrm{CHX}$ following $\mathrm{Tg}$ induction of SGs (40 min) was sufficient to observe disassembly. Like CHX, ISRIB addition disassembled SGs within $10 \mathrm{~min}$, even in the prolonged presence of the stressor $\mathrm{Tg}$ (Figure 3C). Whereas ISRIB restored translation of mRNAs that are liberated from SGs, as seen by the quick recovery in $\left.{ }^{35} \mathrm{~S}\right]$-methionine incorporation, $\mathrm{CHX}$ further reduced protein synthesis (Figure 3D and Figure 3-figure supplement 2). These experiments demonstrate that ISRIB triggers disassembly of pre-formed SGs by loading dissociating mRNAs with actively translating ribosomes.

We next looked at the kinetics of SG disassembly upon ISRIB addition. Strikingly, after only 5 min of ISRIB treatment, Tg-induced SGs were no longer observed in cells (Figure 3E and Video 1). We also investigated the impact of ISRIB on P-bodies, a molecularly distinct class of RNA aggregates that serve as centers of mRNA decay (Kedersha and Anderson, 2009). The mRNA decay factor Dcp1 serves as a marker for these structures, and we visualized them in living cells using the fusion protein Dcp1-RFP. We saw that P-bodies were constitutively present in a percentage of the cells and were not affected by ISRIB treatment or by the stressors used to induce SGs over the time-course experiments explored here (Figure 3E red arrows, Video 2 and data not shown).

\section{Discussion}

ISRIB is the first reported antagonist of the ISR that blocks signaling downstream of all elF2 $\alpha$ kinases. It was shown to have good pharmacokinetic properties and brain penetration, making it a useful tool to study the systemic effects of acute inhibition of the pathway. We showed that ISRIB administration enhances long-term memory in rodents (Sidrauski et al., 2013). More recently, we showed by electrical recordings in brain slices that by preventing AMPAR down-regulation in the post-synaptic neuron, ISRIB blocks mGluR-mediated long-term depression (LTD), an effect that is dependent on elF2 $\alpha$ phosphorylation (Di Prisco et al., 2014). Comprehensive analyses of the cellular effects and kinetics of action of ISRIB are critical for interpretation of its in vivo effects and assessment of its therapeutic potential. 

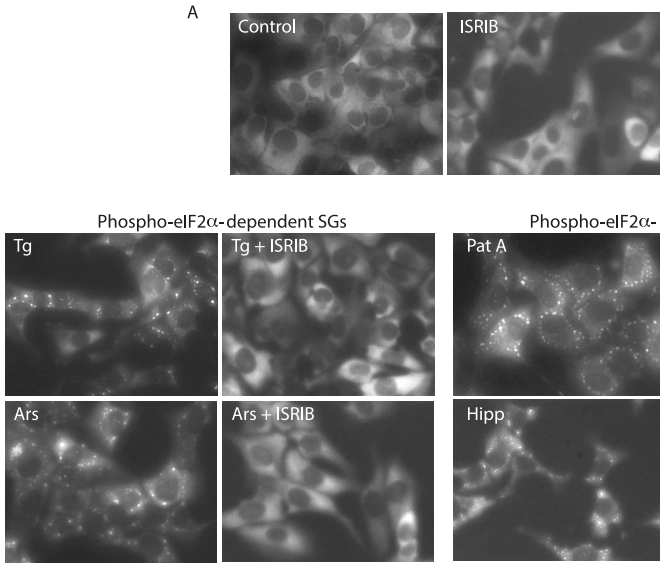

B

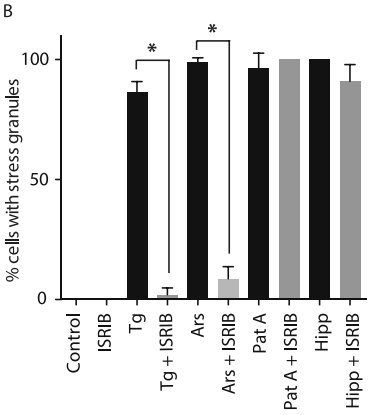

Phospho-elF2 $\alpha$-independent SGs
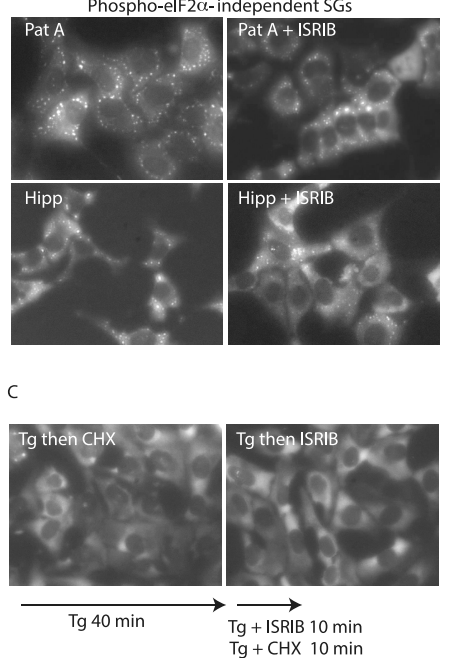

D

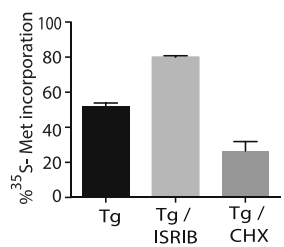

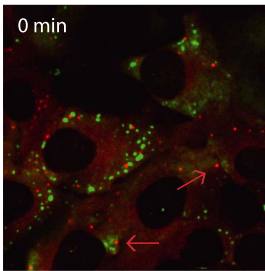
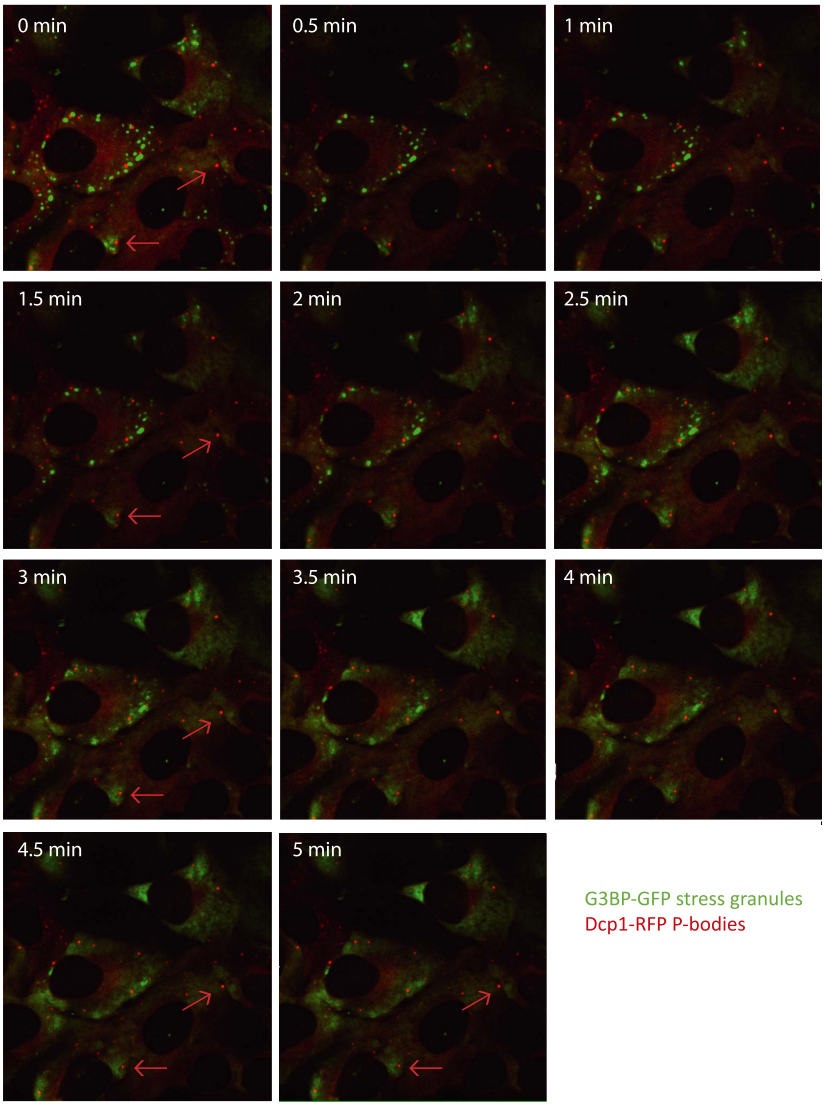

G3BP-GFP stress granules Dcp1-RFP P-bodies

Figure 3. ISRIB addition rapidly dissolves pre-formed stress granules in live cells restoring translation. (A) Live cell imaging of stress granules in U2OS cells stably expressing G3BP-GFP (SG marker). Cells were treated with $200 \mathrm{nM}$ Tg for 40 min, $250 \mu$ M Ars for 30 min, 100 nM Pat A for 30 min, or 300 nM Hipp in the presence or absence of $200 \mathrm{nM}$ ISRIB. Cells were imaged using an epifluorescence microscope. Representative images of at least two biological replicates are shown. (B) Quantitation of the percentage of cells containing stress granules in the different conditions described in $\mathbf{A}$. Images were collected from at least two independent experiments and the number of cells with SGs or no SGs counted. The number of cells analyzed for each

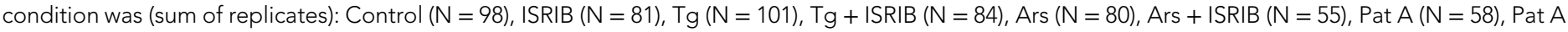
+ ISRIB $(N=50)$, Hipp $(N=41)$ and Hipp + ISRIB $(N=52)$. p-values are derived from a Student's t-test, ${ }^{*} p<0.05$. (C) Stress granules were pre-formed with $\mathrm{Tg}$ for $40 \mathrm{~min}$ (as in Figure $3 \mathrm{~A}$ ) and then $\mathrm{CHX}(50 \mu \mathrm{g} / \mathrm{ml})$ or ISRIB $(200 \mathrm{nM})$ was added to the well, incubated for $10 \mathrm{~min}$ and images were collected. Representative images of at least two biological replicates are shown. (D) ISRIB quickly restores mRNA translation upon disassembly of stress granules. Cells were treated as in $\mathbf{C}$ with $200 \mathrm{nM}$ Tg for $40 \mathrm{~min}$ and then DMSO, CHX (50 $\mu \mathrm{g} / \mathrm{ml})$, or ISRIB (200 nM) was added at the same time as [ $\left.{ }^{35} \mathrm{~S}\right]-\mathrm{methionine}$. Cells were lysed after $15 \mathrm{~min}$, protein was run in an SDS-PAGE gel and radioactivity was measured in each lane $(N=2$, mean \pm SD). (E) ISRIB quickly dissolves stress granules but does not affect P-bodies. Live cell imaging of U2OS cells stably expressing G3BP-GFP (SG marker) and Dcp1-RFP (P-body marker). Cells were treated with $200 \mathrm{nM}$ Tg for 45 min followed by addition of $200 \mathrm{nM}$ ISRIB at $\mathrm{t}=0$ min to the well and then imaged using spinning disk confocal microscopy. Images were collected every $30 \mathrm{~s}$. The red arrows point to two representative P-bodies. Representative images of at least three biological replicates are shown.

DOI: 10.7554/eLife.05033.010

The following figure supplements are available for figure 3:

Figure supplement 1. ISRIB dose response and inactive analog in stress granule assay. DOI: 10.7554/eLife.05033.011

Figure supplement 2. Representative SDS-PAGE gel of $\left[{ }^{35} \mathrm{~S}\right]$-methionine pulse as described in Figure 3D.

DOI: 10.7554/eLife.05033.012

Our translational and transcriptional profiling confirmed that ISRIB treatment of ER-stressed cells substantially and comprehensively blocks the translational effects of elF2 $\alpha$ phosphorylation. ISRIB blocked SG formation that was triggered by elF $2 \alpha$ phosphorylation but did not abolish their assembly 
upon elF4A inhibition; elF4A inhibitors do not cause elF2 $\alpha$ phosphorylation and can induce SGs in elF2 $\alpha^{\text {S51A/S51A }}$ cells (Mazroui et al., 2006; Mokas et al., 2009). These data further support the notion that ISRIB solely inhibits cellular events that are a consequence of elF2 $\alpha$ phosphorylation. In agreement with these observations, we previously showed by polyribosome sedimentation analysis that ISRIB does not reverse bulk translational down-regulation triggered by inhibition of CAP-dependent initiation (Sidrauski et al., 2013). Moreover, ISRIB treatment alone did not induce overall changes in translation or mRNA levels. Taken together these data demonstrate that ISRIB is a pharmacological agent that acutely and specifically blocks the ISR and is thus an invaluable tool for in vivo studies.

\section{Translational regulation upon ISR induction}

The method of ribosome profiling can monitor in vivo translation comprehensively and with nucleotide resolution (Ingolia et al., 2009). We used this method to monitor translation of all cellular mRNAs upon ISR activation. We found that a limited set of mRNAs is preferentially translated in a substantial manner upon a reduction in ternary complex assembly. Although previous large-scale analyses have revealed that almost $45 \%$ of all 5' UTRs have at least one upstream uORF (Calvo et al., 2009; Ingolia et al., 2011), our data revealed that only a few of these mRNAs contain uORFs with regulatory properties that significantly enhance translation of their downstream coding sequences upon elF2 $\alpha$ phosphorylation. The canonical ISR translational targets, ATF4, ATF5, CHOP, and GADD34 mRNAs were significantly induced upon $1 \mathrm{hr}$ treatment with the ER-stressor tunicamycin. The stress-induced, uORF-mediated regulation of GCN4 translation in yeast established the paradigm for this mode of regulation (Dever et al., 1995; Grant et al., 1995). As in mammalian cells, GCN2 is activated in amino acid-starved yeast by the accumulation of uncharged tRNAs, catalyzing elF2 $\alpha$ phosphorylation. The transcript encoding GCN4, a bZIP transcription factor with homology to mammalian ATF4, has four uORFs that modulate translation of its coding sequence upon stress. GCN4 induction is thought to occur via a re-scanning mechanism that allows $40 \mathrm{~S}$ ribosomal subunits to remain mRNA-bound after completing the translation of short reading frames and subsequently reinitiate in the downstream coding sequence after reloading with ternary complex (Hinnebusch, 2005). The select mRNAs that are translationally upregulated in mammalian cells have uORFs that vary in number, length, and distance from the coding sequences. As was observed for GCN4, the uORF2 of ATF4 mRNA showed

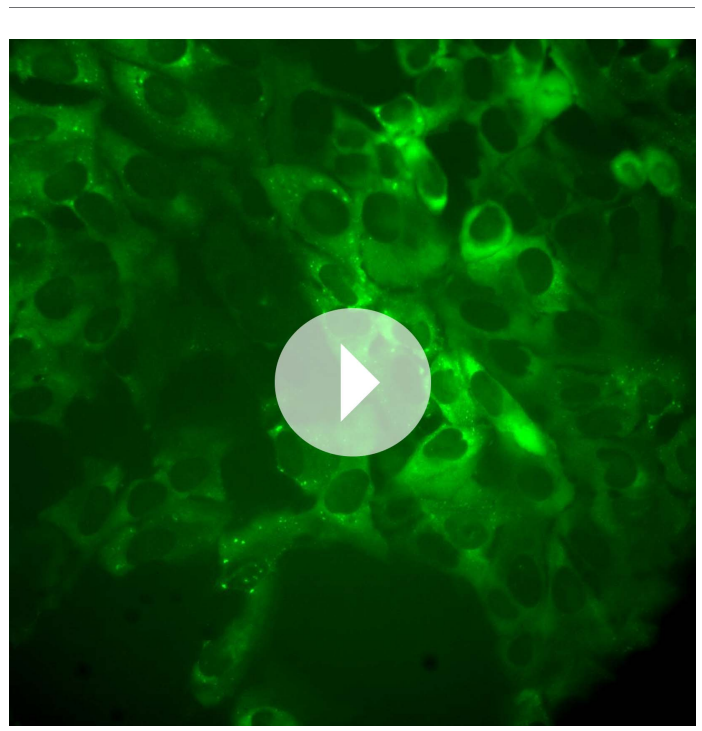

Video 1. ISRIB triggers stress granule disassembly. U2OS cells stably expressing G3BP-GFP (SG marker) and Dcp1-RFP (P-body marker) were treated with 200 $\mathrm{nM} \mathrm{Tg}$ for $40 \mathrm{~min}$ and then $200 \mathrm{nM}$ ISRIB was added at $\mathrm{t}=0 \mathrm{~min}$ to the well and imaged using an epifluorescence microscope. Images of G3BP-GFP (SGs) were collected every $30 \mathrm{~s}$.

DOI: 10.7554/eLife.05033.013 ribosome density, supporting the notion that it is translated under normal growth conditions (Ingolia et al., 2009). Whether the same mechanism of rescanning is utilized by all these mRNAs is not known but, like ATF4, their regulation depends on their uORFs (Vattem and Wek, 2004; Zhou et al., 2008; Lee et al., 2009; Palam et al., 2011).

SLC35A4 is a novel translational target of the ISR. Ribosome profiling of HEK293T cells upon arsenite treatment, a potent inducer of elF2 $\alpha$ phosphorylation, also revealed the increased synthesis of SLC35A4 (Andreev et alo, 2015). It belongs to a large family of nucleotide sugar transporters (NSTs) that are highly conserved transmembrane antiporters localized to the ER or Golgi apparatus (Song, 2013). The role of SLC35A4 in cells is unknown but it may function as the elusive ER-localized UDP-glucose transporter. This hypothesis is particularly attractive in the context of our data because unfolded ER proteins, which trigger the ISR, are continuously de- and re-glucosylated on their N-glycans using UDP-glucose as the glucose donor. Proteins with monoglucosylated N-glycans bind calnexin or calreticulin which promote protein folding. Translational induction of SLC35A4 may thus quickly enhance UDP-glucose transport into 


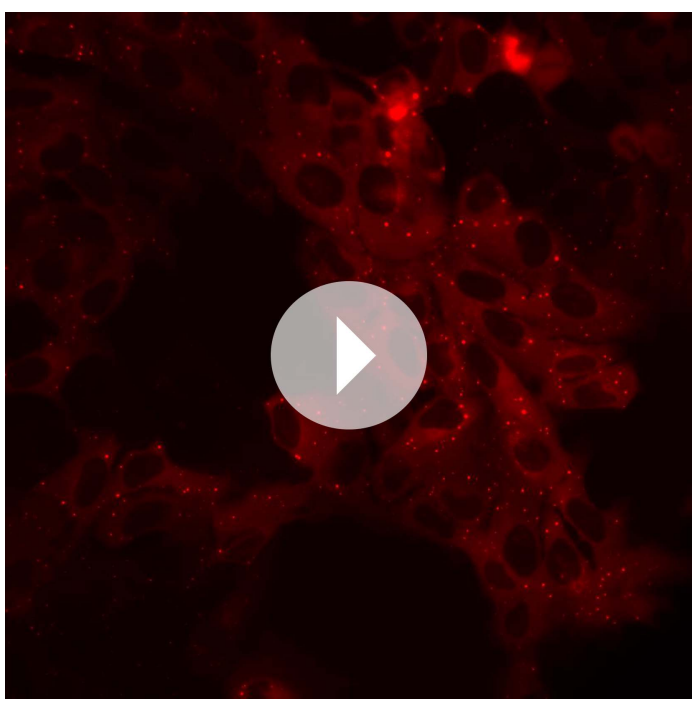

Video 2. ISRIB does not trigger disassembly of P-bodies. Images of Dcp1-RFP (P-bodies) corresponding to the same field of cells as in Video 1 were collected every $30 \mathrm{~s}$.

DOI: 10.7554/eLife.05033.014 the ER lumen upon the accumulation of unfolded proteins in order to promote this pro-folding pathway.

Ribosome profiling upon activation of the UPR uncovered additional mRNAs induced upon elF2 $\alpha$ phosphorylation (our data, Reid et al., 2014; Andreev et alo, 2015). Several of these mRNAs encode for proteins with entirely unknown functions and the remaining targets are involved in a wide range of cellular processes. Whether these ISR-induced translational targets are similarly regulated by the presence of uORFs in their $5^{\prime}$ UTRs remains to be determined with the construction of synthetic translational reporters. ISRIB blocked their differential translation, suggesting that these changes were due to phospho-elF2 $\alpha$. There may be additional transcripts that are synthesized later during ISR activation, downstream of the early transcription factor targets such as ATF4, as well as tissue-specific mRNAs that are controlled by phospho-elF2 $\alpha$. For example, OPHN1 is a neuronspecific mRNA containing uORFs that is translationally upregulated after mGluR engagement and elF2 $\alpha$ phosphorylation and induces LTD. By blocking the effects of phospho-elF2 $\alpha$ in cells, ISRIB also blocks mGluR-dependent LTD (Di Prisco et al., 2014). Ribosome profiling of glutamatergic neurons upon ISR induction may reveal additional transcripts whose translational control contributes to the molecular events underlying memory.

The ribosome profiling data presented here revealed that elF2 $\alpha$ phosphorylation modestly, yet significantly, decreased translation of a large number of ribosomal proteins and elongation factors. Although the decrease in translation of ribosomal proteins and elongation factors upon elF2 $\alpha$ phosphorylation is small in magnitude, its effects on bulk protein synthesis in the cell are significant as these represent a large number of highly expressed proteins. Translation of these mRNAs was previously shown to be under control of mTOR kinase, which regulates mRNA cap-binding factor elF4E via phosphorylation of inhibitory elF4E-binding proteins, thereby adjusting protein synthesis in cells in response to the cell's energy and nutrient status (Ma and Blenis, 2009). In this way, mTOR preferentially regulates translation of a group of mRNAs characterized by $5^{\prime}$ TOP motifs (Hsieh et al., 2012; Thoreen et al., 2012). Upon mTOR inhibition, translation of 5' TOP mRNAs is reduced and the expression of factors required for protein synthesis is diminished.

The observed effect that elF2 $\alpha$ phosphorylation preferentially decreased translation of $5^{\prime}$ TOP mRNAs could, in principle, be due to inhibition of mTOR in response to ER stress. However, ISRIB reversed the translational changes, indicating that they are likely to be downstream consequences of elF2 $\alpha$ phosphorylation. Thus, if these translational changes do reflect altered mTOR activity, then the change in mTOR signaling must result from reduced translation mediated by elF2 $\alpha$ phosphorylation. Alternatively, elF2 $\alpha$ phosphorylation may lead to silencing of these mRNAs by recruiting them into SGs. The RNA binding proteins TIA-1 and TIAR, which are prominently SG-associated, were previously shown to bind to TOP mRNAs, leading to their translational downregulation upon amino acid starvation. This effect required both mTOR inhibition and GCN2 activation, the latter resulting in elF2 phosphorylation (Damgaard and Lykke-Andersen, 2011). SGs also have been shown to recruit signaling molecules including upstream negative regulators of mTORC1 (raptor and DYRK3) and mTORC1 itself, and thus, SG formation may reduce their presence in the cytosol and impede translation of 5' TOP mRNAs (Thedieck et al., 2013; Wippich et al., 2013).

\section{Stress granule dynamics and ISRIB}

The dynamic nature of SGs allowed us to monitor the action of ISRIB upon its addition to live cells in real time. Strikingly, addition of ISRIB to stressed cells with pre-formed SGs lead to their quick dissolution (less than $5 \mathrm{~min}$ ), liberating mRNAs back into the translational pool. A pulse of $\left[{ }^{35} \mathrm{~S}\right]$ - 
methionine confirmed the fast recovery in protein synthesis even in the presence of stress. Although the molecular target of ISRIB remains unknown, its quick action suggests a direct effect on translation initiation. Phospho-elF2 $\alpha$ resistance has been observed both in yeast and in mammalian cells. In yeast, mutations in elF2B (the GEF for elF2) and elF5 (the 48S PIC-associated GTPase-activating protein for elF2) have been reported to make cells insensitive to this phosphorylation event (Vazquez de Aldana and Hinnebusch, 1994; Pavitt et al., 1997, 1998). In mammalian cells, TLR4 engagement in macrophages leads to increased elF2B activity by removal of an inhibitory phosphorylation and insensitivity to ISR activation (Woo et al., 2012). Thus, ISRIB may directly or indirectly enhance the activity of elF2B, elF5, or other initiation factors, thus quickly reversing the cellular effects of phosphorylated elF2 $\alpha$.

SGs contain a large number of RBPs that harbor low complexity sequence domains that nucleate through transient, low affinity interactions (Kato et al., 2012). These RBPs usually contain several RNA-binding domains and can associate with more than one mRNA; this multi-valency further favors the coalescence of RNA-protein granules. A conspicuous feature of some degenerative diseases is the cytoplasmic or nuclear aggregation of RBPs, driven in some cases by pathogenic mutations. TDP-43 and FUS mutations are found in amyotrophic lateral sclerosis (ALS) and frontotemporal lobar degeneration (FTLD) (Li et al., 2013), and mutations in hnRNPA1 and hnRPNPA2/B1 have also been found in ALS (Kim et al., 2013). Recent reports have also described the presence of RNA and RBPs in aggregates that form in prion disease, tauopathies, and Alzheimer's (Vanderweyde et al., 2012; Ash et al., 2014). The impact of these cytosolic aggregates on SG dynamics is not known, though they may hamper the ability of SGs to properly dissolve, thereby contributing to sustained translational attenuation and neurodegeneration. By quickly disassembling SGs even in the presence of stress, ISRIB may provide a useful therapeutic intervention in these diseases by antagonizing the cellular effects of pathogenic RNA-protein assemblies.

\section{Materials and methods}

\section{Chemicals}

Tunicamycin was obtained from Calbiochem EMB Bioscience. Thapsigargin, cycloheximide and sodium arsenite were obtained from Sigma-Aldrich. Hippuristanol and pateamine A were a kind gift from Jerry Pelletier. GSK797800 (PERK inhibitor) was obtained from TRC Inc. ISRIB (Sidrauski et al., 2013) and an inactive analog (754125) (Di Prisco et al., 2014) were synthesized in-house.

\section{Cell culture}

HEK293T, U2OS, and U2OS GFP-G3BP/Dcp1-RFP cells were maintained at $37^{\circ} \mathrm{C}, 5 \% \mathrm{CO}_{2}$ in DMEM media supplemented with 10\% FBS, L-glutamine and antibiotics (penicillin and streptomycin). U2OS cells stably expressing G3BP-GFP/Dcp1-RFP cells were a kind gift from Nancy Kedersha (Kedersha et al., 2008).

\section{Isolation of ribosome footprints and RNA}

HEK293T cells were treated with or without $1 \mu \mathrm{g} / \mathrm{ml}$ of tunicamycin, tunicamycin and ISRIB (200 nM), or ISRIB for $1 \mathrm{hr}$. Cycloheximide (CHX) $(100 \mu \mathrm{g} / \mathrm{ml})$ was added for $2 \mathrm{~min}$, cells were washed with ice cold PBS (with $100 \mu \mathrm{g} / \mathrm{ml}$ of $\mathrm{CHX}$ ) and lysed in $20 \mathrm{mM}$ Tris $\mathrm{pH}=7.4$ (RT), $200 \mathrm{mM} \mathrm{NaCl}, 15 \mathrm{mM} \mathrm{MgCl}, 1 \mathrm{mM}$

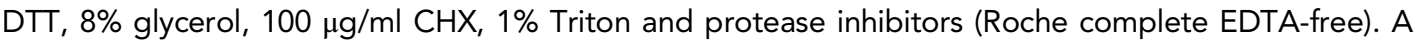
syringe (25G5/8) was used to triturate cells, the lysate was clarified at $12,000 \mathrm{rpm}$ for $10 \mathrm{~min}$ and half of the lysate was used for RNA extraction (Trizol, Invitrogen, Carlsbad, CA) and the other half was digested with RNase I (Ambion). The amount of RNase I and time of incubation was optimized for each sample based on the collapse of polyribosomes to the monosome peak as analyzed by analytical polyribosome gradients. The reaction was quenched with SUPERaseln (Ambion, Life Technologies) and the digested lysate was then loaded on an $800 \mu$ sucrose cushion $1.7 \mathrm{~g}$ of sucrose was dissolved in $3.9 \mathrm{ml}$ of lysis buffer without Triton) and centrifuged in a TLA100.2 rotor at 70,000 rpm for $4 \mathrm{hr}$. The pellet was resuspended in $10 \mathrm{mM}$ Tris $\mathrm{pH}=7(\mathrm{RT})$, and RNA was extracted (phenol/chloroform).

\section{Generation of sequencing libraries and data analysis}

Sequencing libraries were generated as described in Ingolia et al., 2012. For data analysis, we used DESeq as described by Anders and Huber (2010). P-adj values ( $p$-values) were calculated using the R command 'p.adjust' for multiple comparisons and the BH method (Benjamini and Hochberg, 1995) to 
correct for false discovery rate. The data in this publication have been deposited in NCBI's Gene Expression Omnibus and are accessible through GEO series accession number GSE65778.

\section{Immunofluorescence}

U2OS cells were seeded on 4-well chamber slides (Lab-Tek) $18 \mathrm{hr}$ prior to processing for immunofluorescence. Cells (80\% confluent) were fixed with ice-cold methanol. The cells were then rinsed with PBS (Sigma) and blocked for $1 \mathrm{hr}$ at room temperature in 0.5\% BSA in PBS. The cells were then incubated overnight at $4^{\circ} \mathrm{C}$ with an anti-elF3A rabbit antibody (\#3411; Cell Signaling Technology) at a 1:1000 dilution in blocking buffer. The next morning the slides were washed three times (5 min each time) with PBS and then incubated for $1 \mathrm{hr}$ at room temperature in a 1:1000 dilution (in 0.5\% BSA in PBS) of secondary anti-rabbit antibody labeled with Alexa Dye 488 (Molecular Probes). The slides were washed three additional times with PBS. The slides were then mounted with antifade reagent with DAPI (Life Technologies P-36931). Lastly, the slides were imaged using a Zeiss Axiovert 200M epifluorescence microscope.

\section{Live cell microscopy}

U2OS G3BP-GFP/Dcp1-RFP cells were plated in 8-well Lab-Tek chamber slides and switched to imaging media (lacking phenol red) upon addition of different stress inducers. Cells were either imaged using a Zeiss Axiovert 200M epifluorescence microscope or in a heated chamber using a spinning confocal epifluorescence microscope (Eclipse Ti-Nikon) and an Andor iXon3 camera.

\section{Protein analysis}

Cells were washed with PBS and lysed in SDS-PAGE loading buffer (1\% SDS, $62.5 \mathrm{mM}$ Tris- $\mathrm{HCl} \mathrm{pH}$ $6.8,10 \%$ glycerol). Lysates were sonicated and loaded on Any-kD SDS-PAGE gels (BioRad). Proteins were transferred onto nitrocellulose and probed with primary antibodies diluted in Tris-buffered saline supplemented with $0.1 \%$ Tween 20 and 5\% BSA. The following antibodies were used: PERK (D11A8) (1:1000), elF2 $\alpha$ (\#9722; Cell Signaling technology) (1:1000), phospho-elF2 $\alpha$ (Ser51) (44728G; Invitrogen). An HRP-conjugated secondary antibody (Amersham) was employed to detect immune-reactive bands using enhanced chemiluminescence (SuperSignal, Thermo Scientific).

\section{$\left[{ }^{35} \mathrm{~S}\right]-$ methionine incorporation}

U2OS GFP-G3BP/mRFP-DCP1a cells were seeded on 12-well plates, allowed to recover overnight and treated with $100 \mathrm{nM}$ Tg for $40 \mathrm{~min}$. ISRIB $(200 \mathrm{nM})$ or $\mathrm{CHX}(50 \mu \mathrm{g} / \mathrm{ml})$ was added at the same time as $50 \mu \mathrm{Ci}$ of $\left.{ }^{35} \mathrm{~S}\right]$-methionine (Perkin Elmer) and incubated for $15 \mathrm{~min}$. Cells were lysed by addition of SDS-PAGE loading buffer. Lysates were sonicated and equal amounts were loaded on SDS-PAGE gels (BioRad). The gel was dried and radioactive methionine incorporation was detected by exposure to a phosphor-screen and visualized with a Typhoon 9400 Variable Mode Imager (GE Healthcare).

\section{Acknowledgements}

We thank Margaret Elvekrog, Voytek Okreglak, Shelley Starck, and Jirka Peschek for editing the manuscript and the members of the Walter lab for helpful discussions.

\section{Additional information}

Funding

\begin{tabular}{lll} 
Funder & Grant reference number & Author \\
\hline $\begin{array}{l}\text { Howard Hughes Medical } \\
\text { Institute (HHMI) }\end{array}$ & $\begin{array}{l}\text { Carmela Sidrauski, } \\
\text { Peter Walter }\end{array}$ \\
\hline Kinship Foundation & $\begin{array}{l}\text { Searle Scholars Program } \\
\text { 11-SSP-229 }\end{array}$ & Nicholas T Ingolia \\
\hline $\begin{array}{l}\text { National Institutes of } \\
\text { Health (NIH) }\end{array}$ & T32GM007231 & Anna M McGeachy \\
\hline
\end{tabular}


Funder

Carnegie Institution of

Washington

The funders had no role in study design, data collection and interpretation, or the decision to submit the work for publication.

\section{Author contributions}

CS, NTI, Conception and design, Acquisition of data, Analysis and interpretation of data, Drafting or revising the article; AMMG, Acquisition of data, Analysis and interpretation of data, Drafting or revising the article; PW, Analysis and interpretation of data, Drafting or revising the article

\section{References}

Anders S, Huber W. 2010. Differential expression analysis for sequence count data. Genome Biology 11:R106. doi: 10.1186/gb-2010-11-10-r106.

Andreev DE, O'Connor PB, Fahey C, Kenny EM, Terenin IM, Dimitriev SE, Cormican P, Morris DW, Shatsky IN Baranov PV. 2015. Translation of $5^{\prime}$ leaders is pervasive in genes resistant to elF2 repression. eLife 4:e03971. doi: 10.7554/eLife.03971.

Ash PE, Vanderweyde TE, Youmans KL, Apicco DJ, Wolozin B. 2014. Pathological stress granules in Alzheimer's disease. Brain Research 1584:52-58. doi: 10.1016/j.brainres.2014.05.052.

Atkins C, Liu Q, Minthorn E, Zhang S, Figueroa DJ, Moss KG, Stanley TB, Sanders B, Goetz A, Gaul N, Choudhry $A E$, Alsaid $H$, Jucker BM, Axten JM, Kumar R. 2013. Characterization of a novel PERK kinase inhibitor with antitumor and anti-angiogenic activity. Cancer Research 73:1993-2002. doi: 10.1158/0008-5472.CAN-12-3109.

Axten JM, Medina JR, Feng Y, Shu A, Romeril SP, Grant SW, Li WH, Heerding DA, Minthorn E, Mencken T, Atkins C, Liu Q, Rabindran S, Kumar R, Hong X, Goetz A, Stanley T, Taylor JD, Sigethy SD, Tomberlin GH, Hassell AM, Kahler KM, Shewchuk LM, Gampe RT. 2012. Discovery of 7-methyl-5-(1-\{[3-(trifluoromethyl)phenyl]acetyl\}-2,3dihydro-1 H-indol-5-yl)-7 H-pyrrolo[2,3- d]pyrimidin-4-amine (GSK2606414), a potent and selective first-in-class Inhibitor of protein kinase R (PKR)-like endoplasmic reticulum kinase (PERK). Journal of Medicinal Chemistry $\mathbf{5 5}$ 7193-7207. doi: 10.1021/jm300713s.

Benjamini Y, Hochberg Y. 1995. Controlling the False Discovery Rate: A Practical and Powerful Approach to Multiple Testing. Journal of the Royal Statistical Society Series B 57:289-300.

Boyce M, Bryant KF, Jousse C, Long K, Harding HP, Scheuner D, Kaufman RJ, Ma D, Coen DM, Ron D, Yuan J. 2005. A selective inhibitor of elF2alpha dephosphorylation protects cells from ER stress. Science 307:935-939. doi: 10.1126/science.1101902.

Buchan JR, Parker R. 2009. Eukaryotic stress granules: the ins and outs of translation. Molecular Cell 36:932-941. doi: 10.1016/j.molcel.2009.11.020.

Calvo SE, Pagliarini DJ, Mootha VK. 2009. Upstream open reading frames cause widespread reduction of protein expression and are polymorphic among humans. Proceedings of the National Academy of Sciences of USA 106: 7507-7512. doi: 10.1073/pnas.0810916106.

Cencic R, Galicia-Vázquez G, Pelletier J. 2012. Inhibitors of translation targeting eukaryotic translation initiation factor 4A. Methods in Enzymology 511:437-461. doi: 10.1016/B978-0-12-396546-2.00020-6.

Chen T, Ozel D, Qiao Y, Harbinski F, Chen L, Denoyelle S, He X, Zvereva N, Supko JG, Chorev M, Halperin JA, Aktas BH. 2011. Chemical genetics identify elF2 $\alpha$ kinase heme-regulated inhibitor as an anticancer target. Nature Chemical Biology 7:608-614. doi: 10.1038/nchembio.613.

Costa-Mattioli M, Gobert D, Harding H, Herdy B, Azzi M, Bruno M, Bidinosti M, Ben Mamou C, Marcinkiewicz E, Yoshida M, Imataka H, Cuello AC, Seidah N, Sossin W, Lacaille JC, Ron D, Nader K, Sonenberg N. 2005.

Translational control of hippocampal synaptic plasticity and memory by the elF2alpha kinase GCN2. Nature 436: 1166-1173. doi: 10.1038/nature03897.

Costa-Mattioli M, Gobert D, Stern E, Gamache K, Colina R, Cuello C, Sossin W, Kaufman R, Pelletier J, Rosenblum K, Krnjević K, Lacaille JC, Nader K, Sonenberg N. 2007. elF2alpha phosphorylation bidirectionally regulates the switch from short- to long-term synaptic plasticity and memory. Cell 129:195-206. doi: 10.1016/j.cell.2007.01. 050.

Damgaard CK, Lykke-Andersen J. 2011. Translational coregulation of 5'TOP mRNAs by TIA-1 and TIAR. Genes \& Development 25:2057-2068. doi: 10.1101/gad.17355911.

Dang Y, Kedersha N, Low WK, Romo D, Gorospe M, Kaufman R, Anderson P, Liu JO. 2006. Eukaryotic initiation factor 2alpha-independent pathway of stress granule induction by the natural product pateamine $A$. The Journal of Biological Chemistry 281:32870-32878. doi: 10.1074/jbc.M606149200.

Dever TE, Yang W, Aström S, Byström AS, Hinnebusch AG. 1995. Modulation of tRNA(iMet), elF-2, and elF-2B expression shows that GCN4 translation is inversely coupled to the level of elF-2.GTP.Met-tRNA(iMet) ternary complexes. Molecular and Cellular Biology 15:6351-6363.

Di Prisco GV, Huang W, Buffington SA, Hsu CC, Bonnen PE, Placzek AN, Sidrauski C, Krnjević K, Kaufman RJ, Walter P, Costa-Mattioli M. 2014. Translational control of mGluR-dependent long-term depression and objectplace learning by elF2 $\alpha$. Nature Neuroscience 17:1073-1082. doi: 10.1038/nn.3754. 
Grant CM, Miller PF, Hinnebusch AG. 1995. Sequences 5' of the first upstream open reading frame in GCN4 mRNA are required for efficient translational reinitiation. Nucleic Acids Research 23:3980-3988. doi: 10.1093/ nar/23.19.3980.

Harding HP, Novoa I, Zhang Y, Zeng H, Wek R, Schapira M, Ron D. 2000. Regulated translation initiation controls stress-induced gene expression in mammalian cells. Molecular Cell 6:1099-1108. doi: 10.1016/S1097-2765(00) 00108-8.

Harding HP, Zhang Y, Zeng H, Novoa I, Lu PD, Calfon M, Sadri N, Yun C, Popko B, Paules R, Stojdl DF, Bell JC, Hettmann T, Leiden JM, Ron D. 2003. An integrated stress response regulates amino acid metabolism and resistance to oxidative stress. Molecular Cell 11:619-633. doi: 10.1016/S1097-2765(03)00105-9.

Hinnebusch AG. 2005. Translational regulation of GCN4 and the general amino acid control of yeast. Annual Review of Microbiology 59:407-450. doi: 10.1146/annurev. micro.59.031805.133833.

Hinnebusch AG, Lorsch JR. 2012. The mechanism of eukaryotic translation initiation: new insights and challenges. Cold Spring Harbor Perspectives in Biology 4:. doi: 10.1101/cshperspect.a011544.

Hsieh AC, Liu Y, Edlind MP, Ingolia NT, Janes MR, Sher A, Shi EY, Stumpf CR, Christensen C, Bonham MJ, Wang S, Ren P, Martin M, Jessen K, Feldman ME, Weissman JS, Shokat KM, Rommel C, Ruggero D. 2012. The translational landscape of mTOR signalling steers cancer initiation and metastasis. Nature 485:55-61. doi: 10. 1038/nature10912.

Hurtaud C, Gelly C, Bouillaud F, Lévi-Meyrueis C. 2006. Translation control of UCP2 synthesis by the upstream open reading frame. Cellular and Molecular Life Sciences 63:1780-1789. doi: 10.1007/s00018-006-6129-0.

Ingolia NT, Brar GA, Rouskin S, McGeachy AM, Weissman JS. 2012. The ribosome profiling strategy for monitoring translation in vivo by deep sequencing of ribosome-protected mRNA fragments. Nature Protocols 7:1534-1550. doi: 10.1038/nprot.2012.086.

Ingolia NT, Ghaemmaghami S, Newman JR, Weissman JS. 2009. Genome-wide analysis in vivo of translation with nucleotide resolution using ribosome profiling. Science 324:218-223. doi: 10.1126/science.1168978.

Ingolia NT, Lareau LF, Weissman JS. 2011. Ribosome profiling of mouse embryonic stem cells reveals the complexity and dynamics of mammalian proteomes. Cell 147:789-802. doi: 10.1016/j.cell.2011.10.002.

Jackson RJ, Hellen CUT, Pestova TV. 2010. The mechanism of eukaryotic translation initiation and principles of its regulation. Nature Reviews Molecular Cell Biology 11:113-127. doi: 10.1038/nrm2838.

Jammi NV, Whitby LR, Beal PA. 2003. Small molecule inhibitors of the RNA-dependent protein kinase. Biochemical and Biophysical Research Communications 308:50-57. doi: 10.1016/S0006-291X(03)01318-4.

Kato M, Han TW, Xie S, Shi K, Du X, Wu LC, Mirzaei H, Goldsmith EJ, Longgood J, Pei J, Grishin NV,Frantz DE, Schneider JW, Chen S, Li L, Sawaya MR, Eisenberg D, Tycko R, McKnight SL. 2012. Cell-free formation of RNA granules: low complexity sequence domains form dynamic fibers within hydrogels. Cell 149:753-767. doi: 10. 1016/j.cell.2012.04.017.

Kedersha N, Cho MR, Li W, Yacono PW, Chen S, Gilks N, Golan DE, Anderson P. 2000. Dynamic shuttling of TIA-1 accompanies the recruitment of mRNA to mammalian stress granules. The Journal of Cell Biology 151: 1257-1268. doi: 10.1083/jcb.151.6.1257.

Kedersha N, Anderson P. 2009. Chapter 4-Regulation of translation by stress granules and processing bodies. Elsevier inc.

Kedersha N, Chen S, Gilks N, Li W, Miller IJ, Stahl J, Anderson P. 2002. Evidence that ternary complex (elF2-GTPtRNA(i)(Met))-deficient preinitiation complexes are core constituents of mammalian stress granules. Molecular Biology of the Cell 13:195-210. doi: 10.1091/mbc.01-05-0221.

Kedersha N, Tisdale S, Hickman T, Anderson P. 2008. Real-time and quantitative imaging of mammalian stress granules and processing bodies. Methods in Enzymology 448:521-552. doi: 10.1016/S0076-6879(08)02626-8.

Kim HJ, Kim NC, Wang YD, Scarborough EA, Moore J, Diaz Z, MacLea KS, Freibaum B, Li S, Molliex A, Kanagaraj AP, Carter R, Boylan KB, Wojtas AM, Rademakers R, Pinkus JL, Greenberg SA, Trojanowski JQ, Traynor BJ, Smith BN, Topp S, Gkazi AS, Miller J, Shaw CE, Kottlors M, Kirschner J, Pestronk A, Li YR, Ford AF, Gitler AD, Benatar M, King OD, Kimonis VE, Ross ED, Weihl CC, Shorter J, Taylor JP. 2013. Mutations in prion-like domains in hnRNPA2B1 and hnRNPA1 cause multisystem proteinopathy and ALS. Nature 495:467-473. doi: 10.1038/ nature11922.

Kim MS, Pinto SM, Getnet D, Nirujogi RS, Manda SS, Chaerkady R, Madugundu AK, Kelkar DS, Isserlin R, Jain S, Jain S, Thomas JK, Muthusamy B, Leal-Rojas P, Kumar P, Sahasrabuddhe NA, Balakrishnan L, Advani J, George B, Renuse S, Selvan LD, Patil AH, Nanjappa V, Radhakrishnan A, Prasad S, Subbannayya T, Raju R, Kumar M, Sreenivasamurthy SK, Marimuthu A, Sathe GJ, Chavan S, Datta KK, Subbannayya Y, Sahu A, Yelamanchi SD, Jayaram S, Rajagopalan P, Sharma J, Murthy KR, Syed N, Goel R, Khan AA, Ahmad S, Dey G, Mudgal K, Chatterjee A, Huang TC, Zhong J, Wu X, Shaw PG, Freed D, Zahari MS, Mukherjee KK, Shankar S, Mahadevan A, Lam H, Mitchell CJ, Shankar SK, Satishchandra P, Schroeder JT, Sirdeshmukh R, Maitra A, Leach SD, Drake CG, Halushka MK, Prasad TS, Hruban RH, Kerr CL, Bader GD, lacobuzio-Donahue CA, Gowda H, Pandey A. 2014. A draft map of the human proteome. Nature 509:575-581. doi: 10.1038/nature13302.

Krishnamoorthy T, Pavitt GD, Zhang F, Dever TE, Hinnebusch AG. 2001. Tight binding of the phosphorylated alpha subunit of initiation factor 2 (elF2alpha) to the regulatory subunits of guanine nucleotide exchange factor elF2B is required for inhibition of translation initiation. Molecular and Cellular Biology 21:5018-5030. doi: 10. 1128/MCB.21.15.5018-5030.2001.

Lee S, Liu B, Lee S, Huang SX, Shen B, Qian SB. 2012. Global mapping of translation initiation sites in mammalian cells at single-nucleotide resolution. Proceedings of the National Academy of Sciences of USA 109:E2424-E2432. doi: 10.1073/pnas.1207846109. 
Lee YY, Cevallos RC, Jan E. 2009. An upstream open reading frame regulates translation of GADD34 during cellular stresses that induce elF2alpha phosphorylation. The Journal of Biological Chemistry 284:6661-6673. doi: 10.1074/jbc.M806735200.

Li YR, King OD, Shorter J, Gitler AD. 2013. Stress granules as crucibles of ALS pathogenesis. The Journal of Cell Biology 201:361-372. doi: 10.1083/jcb.201302044.

Lu M, Lawrence DA, Marsters S, Acosta-Alvear D, Kimmig P, Mendez AS, Paton AW, Paton JC, Walter P, Ashkenazi A. 2014. Cell death. Opposing unfolded-protein-response signals converge on death receptor 5 to control apoptosis. Science 345:98-101. doi: 10.1126/science.1254312.

Lu PD, Harding HP, Ron D. 2004. Translation reinitiation at alternative open reading frames regulates gene expression in an integrated stress response. The Journal of Cell Biology 167:27-33. doi: 10.1083/jcb.200408003.

Ma XM, Blenis J. 2009. Molecular mechanisms of mTOR-mediated translational control. Nature Reviews Molecular Cell Biology 10:307-318. doi: 10.1038/nrm2672.

Mandal S, Mandal A, Johansson HE, Orjalo AV, Park MH. 2013. Depletion of cellular polyamines, spermidine and spermine, causes a total arrest in translation and growth in mammalian cells. Proceedings of the National Academy of Sciences of USA 110:2169-2174. doi: 10.1073/pnas.1219002110.

Mazroui R, Sukarieh R, Bordeleau ME, Kaufman RJ, Northcote P, Tanaka J, Gallouzi I, Pelletier J. 2006. Inhibition of ribosome recruitment induces stress granule formation independently of eukaryotic initiation factor 2alpha phosphorylation. Molecular Biology of the Cell 17:4212-4219. doi: 10.1091/mbc.E06-04-0318.

Meyuhas O. 2000. Synthesis of the translational apparatus is regulated at the translational level. European Journal of Biochemistry 267:6321-6330. doi: 10.1046/j.1432-1327.2000.01719.x.

Mokas S, Mills JR, Garreau C, Fournier MJ, Robert F, Arya P, Kaufman RJ, Pelletier J, Mazroui R. 2009. Uncoupling stress granule assembly and translation initiation inhibition. Molecular Biology of the Cell 20:2673-2683. doi: 10. 1091/mbc.E08-10-1061.

Mollet S, Cougot N, Wilczynska A, Dautry F, Kress M, Bertrand E, Weil D. 2008. Translationally repressed mRNA transiently cycles through stress granules during stress. Molecular Biology of the Cell 19:4469-4479. doi: 10. 1091/mbc.E08-05-0499.

Palam LR, Baird TD, Wek RC. 2011. Phosphorylation of elF2 facilitates ribosomal bypass of an inhibitory upstream ORF to enhance CHOP translation. Journal of Biological Chemistry 286:10939-10949. doi: 10.1074/jbc.M110. 216093.

Pavitt GD, Ramaiah KV, Kimball SR, Hinnebusch AG. 1998. elF2 independently binds two distinct elF2B subcomplexes that catalyze and regulate guanine-nucleotide exchange. Genes \& Development 12:514-526. doi: 10.1101/gad.12.4.514.

Pavitt GD, Yang W, Hinnebusch AG. 1997. Homologous segments in three subunits of the guanine nucleotide exchange factor elF2B mediate translational regulation by phosphorylation of elF2. Molecular and Cellular Biology 17:1298-1313.

Pavitt GD, Ron D. 2012. New insights into translational regulation in the endoplasmic reticulum unfolded protein response. Cold Spring Harbor Perspectives in Biology 4:. doi: 10.1101/cshperspect.a012278.

Reid DW, Chen Q, Tay AS, Shenolikar S, Nicchitta CV. 2014. The unfolded protein response triggers selective mRNA release from the endoplasmic reticulum. Cell 158:1362-1374. doi: 10.1016/j.cell.2014.08.012.

Scheuner D, Song B, McEwen E, Liu C, Laybutt R, Gillespie P, Saunders T, Bonner-Weir S, Kaufman RJ. 2001. Translational control is required for the unfolded protein response and in vivo glucose homeostasis. Molecular Cell 7:1165-1176. doi: 10.1016/S1097-2765(01)00265-9.

Sidrauski C, Acosta-Alvear D, Khoutorsky A, Vedantham P, Hearn BR, Li H, Gamache K, Gallagher CM, Ang KK, Wilson C, Okreglak V, Ashkenazi A, Hann B, Nader K, Arkin MR, Renslo AR, Sonenberg N, Walter P. 2013. Pharmacological brake-release of mRNA translation enhances cognitive memory. eLife 2:e00498. doi: 10.7554/ eLife.00498.

Song Z. 2013. Roles of the nucleotide sugar transporters (SLC35 family) in health and disease. Molecular Aspects of Medicine 34:590-600. doi: 10.1016/j.mam.2012.12.004.

Tabas I, Ron D. 2011. Integrating the mechanisms of apoptosis induced by endoplasmic reticulum stress. Nature Cell Biology 13:184-190. doi: 10.1038/ncb0311-184.

Tang H, Hornstein E, Stolovich M, Levy G, Livingstone M, Templeton D, Avruch J, Meyuhas O. 2001. Amino acidinduced translation of TOP mRNAs is fully dependent on phosphatidylinositol 3-kinase-mediated signaling, is partially inhibited by rapamycin, and is independent of S6K1 and rpS6 phosphorylation. Molecular and Cellular Biology 21:8671-8683. doi: 10.1128/MCB.21.24.8671-8683.2001.

Thedieck K, Holzwarth B, Prentzell MT, Boehlke C, Kläsener K, Ruf S, Sonntag AG, Maerz L, Grellscheid S-N, Kremmer E, Nitschke R, Kuehn EW, Jonker JW, Groen AK, Reth M, Hall MN, Baumeister R. 2013. Inhibition of mTORC1 by astrin and stress granules prevents apoptosis in cancer cells. Cell 154:859-874. doi: 10.1016/j.cell. 2013.07.031.

Thoreen CC, Chantranupong L, Keys HR, Wang T, Gray NS, Sabatini DM. 2012. A unifying model for mTORC1mediated regulation of mRNA translation. Nature 485:109-113. doi: 10.1038/nature11083.

Vanderweyde T, Yu H, Varnum M, Liu-Yesucevitz L, Citro A, Ikezu T, Duff K, Wolozin B. 2012. Contrasting pathology of the stress granule proteins TIA-1 and G3BP in tauopathies. Journal of Neuroscience 32:8270-8283. doi: 10.1523/JNEUROSCI.1592-12.2012.

Vattem KM, Wek RC. 2004. Reinitiation involving upstream ORFs regulates ATF4 mRNA translation in mammalian cells. Proceedings of the National Academy of Sciences of USA 101:11269-11274. doi: 10.1073/pnas. 0400541101. 
Vazquez de Aldana CR, Hinnebusch AG. 1994. Mutations in the GCD7 subunit of yeast guanine nucleotide exchange factor elF-2B overcome the inhibitory effects of phosphorylated elF-2 on translation initiation. Molecular and Cellular Biology 14:3208-3222.

Walter P, Ron D. 2011. The unfolded protein response: from stress pathway to homeostatic regulation. Science 334:1081-1086. doi: 10.1126/science.1209038.

Wek RC, Jiang HY, Anthony TG. 2006. Coping with stress: elF2 kinases and translational control. Biochemical Society Transactions 34:7-11.

Wippich F, Bodenmiller B, Trajkovska MG, Wanka S, Aebersold R, Pelkmans L. 2013. Dual specificity kinase DYRK3 Couples stress granule condensation/dissolution to mTORC1 signaling. Cell 152:791-805. doi: 10.1016/j.cell. 2013.01.033.

Woo CW, Kutzler L, Kimball SR, Tabas I. 2012. Toll-like receptor activation suppresses ER stress factor CHOP and translation inhibition through activation of elF2B. Nature Cell Biology 14:192-200. doi: 10.1038/ncb2408.

Yu L, Kelly U, Ebright JN, Malek G, Saloupis P, Rickman DW, McKay BS, Arshavsky VY, Bowes Rickman C. 2007. Oxidative stress-induced expression and modulation of Phosphatase of Regenerating Liver-1 (PRL-1) in mammalian retina. Biochimica Et Biophysica Acta 1773:1473-1482. doi: 10.1016/j.bbamcr.2007.06.005.

Zhou D, Palam LR, Jiang L, Narasimhan J, Staschke KA, Wek RC. 2008. Phosphorylation of elF2 directs ATF5 translational control in response to diverse stress conditions. The Journal of Biological Chemistry 283:7064-7073. doi: 10.1074/jbc.M708530200.

Zhu PJ, Huang W, Kalikulov D, Yoo JW, Placzek AN, Stoica L, Zhou H, Bell JC, Friedlander MJ, Krnjević K, Noebels JL, Costa-Mattioli M. 2011. Suppression of PKR promotes network excitability and enhanced Cognition by Interferon- $\gamma$-mediated disinhibition. Cell 147:1384-1396. doi: 10.1016/j.cell.2011.11.029. 